\title{
Mast cells in meningiomas and brain inflammation
}

\author{
Stavros Polyzoidis ${ }^{1}$, Triantafyllia Koletsa ${ }^{2}$, Smaro Panagiotidou, ${ }^{3,4}$, Keyoumars Ashkan ${ }^{1}$ \\ and Theoharis C. Theoharides $3,4,5,6,7^{*}$
}

\begin{abstract}
Background: Research focus in neuro-oncology has shifted in the last decades towards the exploration of tumor infiltration by a variety of immune cells and their products. T cells, macrophages, B cells, and mast cells (MCs) have been identified.

Methods: A systematic review of the literature was conducted by searching PubMed, EMBASE, Google Scholar, and Turning Research into Practice (TRIP) for the presence of MCs in meningiomas using the terms meningioma, inflammation and mast cells.
\end{abstract}

Results: MCs have been detected in various tumors of the central nervous system (CNS), such as gliomas, including glioblastoma multiforme, hemangioblastomas, and meningiomas as well as metastatic brain tumors. MCs were present in as many as $90 \%$ of all high-grade meningiomas mainly found in the perivascular areas of the tumor. A correlation between peritumoral edema and MCs was found.

Interpretation: Accumulation of MCs in meningiomas could contribute to the aggressiveness of tumors and to brain inflammation that may be involved in the pathogenesis of additional disorders.

\section{Introduction}

Meningiomas are primary extra-axial tumors of the central nervous system (CNS) with an incidence of $\sim 2$ in 100,000 in adults [1]. There is an approximate 3:1 female predominance of these tumors mainly attributed to the action of oestrogens [2-4]. While meningiomas represent $15 \%$ of intracranial, $25 \%$ of intraspinal, and $28 \%$ of primary CNS tumors, they usually are not at the center of research focus, probably due to their predominantly benign nature, which results in favorable outcomes. However, a minority of meningiomas is found to be more aggressive, invade brain parenchyma, present with significant degree of peritumoral edema, recur, and subsequently have an aggressive course with increased morbidity and mortality [5].

Meningiomas are commonly associated with headaches, imbalance, vision disturbance, and other neurologic problems [6] that could be quite debilitating. Based on the

\footnotetext{
* Correspondence: theoharis.theoharides@tufts.edu

${ }^{3}$ Molecular Immunopharmacology and Drug Discovery, Department of Integrative Physiology and Pathobiology, Tufts University School of Medicine, 136 Harrison Avenue, Suite J304, Boston, MA 02111, USA

${ }^{4}$ Sackler School of Graduate Biomedical Sciences, Tufts University School of Medicine, Tufts Medical Center, Boston, MA, USA

Full list of author information is available at the end of the article
}

2007 (current) classification and grading system of the World Health Organization (WHO) for nervous tissue tumors [7], meningiomas belong to the meningothelial-cell tumors of the meninges and are classified in three grades (Table 1): grade I-slow growing, noncancerous; grade II-atypical with mixed noncancerous and cancerous features; and grade III-cancerous and fast growing. The vast majority of meningiomas is graded as I and is benign [5] with treatment consisting solely of surgical resection, which results in recurrence rates of $2-3 \%$ following total resection [8]. For selected small or incompletely excised tumors, focused radiotherapy is an additional option [9]. However, treatment of meningiomas encasing crucial neural and vascular structures, and of more aggressive histological types, such as anaplastic (grade III), can be more challenging. The current standard of care for the latter comprises surgery and additional radiotherapy, which contributes to a mean overall survival of 3.3 years for anaplastic meningiomas based on a retrospective study $[1,10]$. Mean progression-free survival is 11.5 and 2.7 years, respectively [11].

Mainstream theory about tumorigenesis of meningiomas favors origin from arachnoid cap cells, while 
Table 1 Classification of meningiomas

1. Grade I. Meningothelial, fibrous (fibroblastic), transitional (mixed),
psammomatous, angiomatous, microcystic, secretory,
lymphoplasmacyte-rich, metaplastic
2. Grade II. Chordoid, clear cell, atypical, brain-invasive
3. Grade III. Papillary, rhabdoid, and anaplastic (malignant)

intraventricular ones probably develop from meningothelial inclusion bodies of the tela choroidea arachnoid [12]. Tumor formation can be triggered or affected by various factors, such as genetic [classically the neurofibromatosis 2 (NF2) gene] [13, 14], previous radiotherapy, and possibly head trauma $[15,16]$. Meningiomas can be infiltrated by various types of cells, mainly of the immune system, such as macrophages, CD8 lymphocytes, and mast cells (MCs) $[17,18]$. Some meningioma variants have been associated with systematic inflammatory syndromes as well, for example, Castleman's syndrome [19]. This could either represent an innate immune response to the newly forming tumor or could be a factor contributing to tumorigenesis. As such, it has been shown that common variations in the genetics of the innate immune system, such as T-cell regulation, chronic inflammation, IgE, and allergic reactions, may increase the risk of meningioma [20-24]. Presently, the exact nature of this interaction between meningiomas and the immune system, and its potential effect on tumor growth, remains unclear.

A retrospective immunohistochemical study investigated mononuclear cell infiltration in a series of 34 meningiomas [18]. Such infiltrates mainly comprised of T cells and macrophages, with the latter being significantly associated with high cellularity, nuclear atypia, and frequent mitotic figures intra- and perivascularly. MCs were seen in $9 / 32$ (28 \%) tumors, among which the most prevalent subtype was the syncytial in agreement with previous studies. Prognostic significance of this finding was unclear in this study.

MCs of various phenotypes were found mainly perivascularly and sporadically in lobules of connective tissue in all types of meningiomas, including malignant ones independent of growth rate, grading, and the degree of calcification [25].

A rare case of a convexity meningioma with an unusually high number of MCs, which presented as chronic subdural hematoma, was described by Popovic et al. [26]. It was suggested that intratumoral histamine release, histamine-associated vasodilation, and subsequent tumoral hemorrhage in MC-rich meningiomas may be an underlying mechanism in a small proportion of meningioma-related subdural hematomas.

Incidental findings on meningiomas and MCs have also been reported in the context of studies with other objectives. During examination of the distribution of the glial fibrillary acidic protein (GFAP) in 131 paraffin-embedded sections of brain neoplasms deriving from either surgical or postmortem specimens [27], MCs were identified in one case of meningothelial meningioma [28].

\section{Methods \\ Objectives}

The aim of this study was to review the literature investigating the presence of MCs in meningiomas and their potential interaction. More specifically, the literature was reviewed for the role of this interface and its contribution to tumorigenesis, biological behavior, tumor growth, and tumor suppression.

\section{Selection of articles}

A systematic review of the literature was conducted by a thorough online search in PubMed, EMBASE, Google Scholar, and Turning Research into Practice (TRIP) to retrieve all articles evaluating the presence and role of MCs in intracranial meningiomas. In the PubMed MeSH database system, we used the terms meningioma, inflammation and mast cells ["Meningiomas" (Mesh) AND "Mast cells" (Mesh)]. Furthermore, to eliminate the chance of missing any other published data, references from past relevant publications were also evaluated. Perspective and retrospective clinical studies, including case reports, as well as experimental studies in animals were included only in the English language.

\section{Results}

\section{Mast cells in brain inflammation}

There is growing interest is the presence of MCs in meningiomas, because of the conflicting reports with regard to the association of MCs with meningioma grade $[24,29,30]$. Furthermore, there is increasing evidence suggesting MCs may stimulate neoplastic growth [31, 32], while others support a potential dual role of MCs contributing both to tumorigenesis and tumor-suppression processes in various types of cancers [33].

MCs originate from a bone marrow progenitor and subsequently develop different phenotype characteristics locally in tissues. Their range of functions is wide and includes participation in allergic reactions, innate and adaptive immunity, inflammation, and autoimmunity [34]. In the human brain, MCs can be located in various areas, such as the pituitary stalk, the pineal gland, the area postrema, the choroid plexus, thalamus, hypothalamus, and the median eminence [35]. In the meninges, they are found within the dural layer in association with vessels and terminals of meningeal nociceptors [36]. MCs have a distinct feature compared to other hematopoietic cells in that they reside in the brain [37]. MCs contain numerous granules and secrete an abundance of prestored mediators such as corticotropin-releasing hormone $(\mathrm{CRH})$, neurotensin $(\mathrm{NT})$, substance P (SP), tryptase, chymase, vasoactive intestinal 
peptide (VIP), vascular endothelial growth factor (VEGF), TNF, prostaglandins, leukotrienes, and varieties of chemokines and cytokines some of which are known to disrupt the integrity of the blood-brain barrier (BBB) [38-40].

They key role of MCs in inflammation [34] and in the disruption of the BBB [41-43] suggests areas of importance for novel therapy research. Increasing evidence also indicates that MCs participate in neuroinflammation directly [44-46] and through microglia stimulation [47], contributing to the pathogenesis of such conditions such as headaches, [48] autism [49], and chronic fatigue syndrome [50]. In fact, a recent review indicated that peripheral inflammatory stimuli can cause microglia activation [51], thus possibly involving MCs outside the brain.

\section{Mast cells in meningiomas}

MCs have been found to infiltrate both primary and metastatic tumors [52]. For instance, MCs infiltrated and proliferated both in the tumor mass and in the area adjacent to tumor-associated vessels in an experimental model of high-grade gliomas, including glioblastoma multiforme [53]. In addition, stem cell factor (SCF), the main growth factor of MCs, was mainly expressed around the tumorassociated vessels, and it was proposed that the tumorderived CXCL12/CXCR4 attracted MCs [53].

Polajeva et al. reported that MCs were detected in both low- and high-grade gliomas [54], and it was concluded that (a) MC accumulation in these tumors increased as grade malignancy increased, (b) neutralization of the glioma-derived macrophage migration inhibitory factor (MIF) reduced the extent of MC migration, (c) the magnitude of MC recruitment correlated with the level of MIF, and (d) MIF-induced accumulation of MCs in vivo was associated with activation of the signal transducer and activator of transcription 5 (STAT5) [54]. Additionally, MCs have been detected in increased numbers in the infiltrating zones of medulloblastomas and gliomas [55], while they were also found to be erythropoietin (EPO)-positive in $50 \%$ of a series of hemangioblastoma specimens [56].

Moreover, it has been proposed that metastatic brain tumors can be promoted by stress (unavoidable in patients with cancer) [57] which activates brain MCs to disrupt the $\mathrm{BBB}$ via the CRH pathway [58]. This increases $\mathrm{BBB}$ permeability for primary cancer cells deriving from the periphery, which can subsequently infiltrate brain parenchyma and metastasize as was shown for rat mammary adenocarcinoma [59]. In two case reports, breast cancer cells were reported to be associated with meningiomas $[60,61]$ and breast cancer may be concurrent with meningiomas [62]. Immune responses, such as the peritumoral collection of MCs, are increasingly considered to augment tumor growth and metastasis $[33,57,63]$.
Two retrospective studies [24, 29] evaluated MCs, by tryptase immunostaining, in a series of meningiomas of various grades. Specimens were divided in two groups of low-grade meningiomas (WHO grade I) and high-grade meningiomas (WHO grades II and III). In the first study [24], 70 cases were analyzed. In the group of low-grade tumors $(n=63)$, MCs were seen in $20 / 63$ cases $(31.8 \%)$, with strong diffused immunoreaction in $8 / 20$ mostly next to blood vessels disseminated intratumorally; all psammomatous, secretory, and meningothelial meningiomas were negative for MCs, whereas all fibrous and transitional meningiomas were positive. Interestingly, CT brain images of all MC-positive low-grade meningiomas showed marked peritumoral edema [24].

In the second group $(n=7), 6 / 7(86 \%)$ tumors were positive for MCs and all presented with peritumoral edema on CT. One anaplastic meningioma was strongly immunopositive, while the rest of the high-grade meningiomas showed focal, but disseminated, positive immunoreaction for tryptase [24]. The second study [29], was conducted on 154 cases, and apart from MCs, it also evaluated the expression of hypoxia-inducible factor-1 (HIF-1), which is a marker of hypoxia found to be correlated with grade and progression of many cancers including glioblastoma [64]. In the group of low-grade meningiomas $(n=104)$, MCs were seen in 42 cases (40.4\%), with strong diffused immunoreaction in $17 / 42$. In the group of high-grade meningiomas $(n=50), 45$ (90\%) of tumors were positive for MCs, with strong immunoreaction in 6/45 cases. MCs were observed not only next to blood vessels but also within the tumor [29].

Based on the Steinhoff classification of peritumoral edema [65], this study showed a statistically significant association between HIF-1 expression, tryptase expression, and the presence of peritumoral brain edema, as well as between MC accumulation and HIF-1 expression based on meningioma grading [29]. MC mediators such as histamine, serotonin, or VEGF might significantly contribute to the formation of peritumoral edema.

Tirakotai et al. studied secretory meningiomas (grade I), which were found to be infiltrated by a higher number of MCs compared to other types (nonsecretory meningiomas). Higher number of MCs was found mainly in and around the pseudopsammoma bodies of secretory meningiomas [66] Eparil et al. and Tina-Suck et al. investigated 12 and 10 cases, respectively, of chordoid meningiomas (grade II) $[67,68]$. Both reported a significant number of MCs in this meningioma variant. The first observed MCs both within the myxoid stroma and the epithelial cell islands, by using toluidine blue and Giemsa stains, in $100 \%$ of cases. MCs were sparsely populated, granulated, single in arrangement, and more frequently seen at the interface regions [67]. The second observed MCs present both in the connective tissue stroma and the epithelial cell 
islands in all specimens, using positive Periodic Acid Schiff (PAS) and mucicarmine stains [68]. In contrast, another study [30] reported that MCs had poor associations with meningioma tumor grading.

\section{Mast cells in cystic meningiomas}

An interesting role of MCs in meningiomas was revealed in a retrospective study investigating microcystic and cystic changes in 397 meningiomas [69]. Such changes were present in about $10 \%$ of these tumors, mainly of the meningothelial type (grade I), and were associated with permeability disturbances and increased number of MCs. Here we show the presence of MCs in dura and bone infiltrated by meningioma of the meningothelial type grade 1 stained for tryptase (Fig. 1) and CD117 (c-kit, the tyrosine kinase surface receptor for stem cell factor) (Fig. 2). It should be noted that these MCs do not appear degranulated. We recently reported that MCs infiltrating pancreatic adenocarcinoma were also increased, but not degranulated in contrast to MCs in acute pancreatitis that were increased in number, but degranulated [70].

\section{Meningiomas and perivascular edema}

Cerebral edema is quite common in intracranial meningiomas. In one study of 68 meningiomas evaluated by computed tomography, $40 \%$ had significant edema [71]. Another review concluded that intracranial meningiomas were associated with brain edema in 50-66 \% of cases [72]. In fact, edema has been considered a prognostic factor for meningiomas and metastases, but not gliomas [73]. Moreover, there was a strong correlation between brain edema and shape of tumor margins and signal intensity on magnetic resonance imaging of 51 meningiomas studied [74]. Peritumoral edema may be due to increased expression of vascular endothelial growth factor (VEGF) [75, 76]. In fact, meningiomas can secrete VEGF-A themselves [77]. It is of interest that MCs can secrete large quantities of VEGF especially in response to CRH [78], which can be secreted by MCs [79] and by metastatic cancer cells [80].

Meningiomas are well known to present with severe headaches, even when tumors are small with little edema, and mass effect alone is insufficient to account for this symptom [81, 82]. It is therefore of interest that MCs have been implicated in the pathogenesis of migraines [38] and meningeal MC-neuron interactions are increasingly invoked in the pathophysiology of headaches [83, 84]. Meningeal inflammation was also regarded critical in seizures [85], and there have been a number of cases of patients with seizures due to underlying mastocytosis $[46,86]$.

The association of MCs with perivascular edema is also important because it may indicate disruption of the $\mathrm{BBB}$, which worsens by stress and contributes to brain metastases [57], multiple sclerosis [87], autism [35, 88], and brain "fog" [89]. It may, therefore, be important to
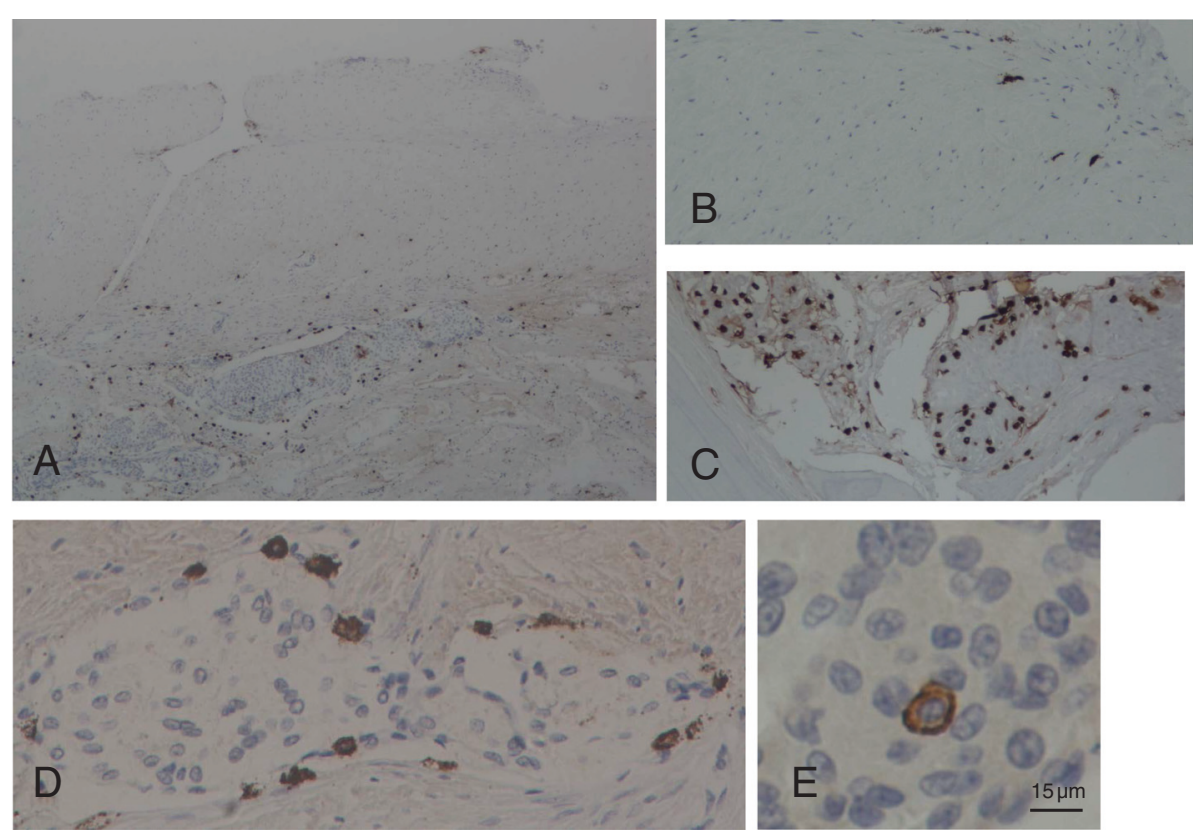

Fig. 1 Photomicrographs of tissue samples of dura and bone infiltrated by meningioma of the meningothelial type grade I obtained from a brain lesion following a left-left frontotemporal craniectomy. Mast cells were stained immunohistochemically for the presence of tryptase (brown color). a Dura showing the upper unaffected part and the lower part infiltrated meningioma cells (blue) and accumulated mast cells (brown); magnification $=\times 40$. $\mathbf{b}$ Unaffected dura; magnification $=\times 100$. $\mathbf{c}$ Bone infiltrated by meningioma cells showing a cluster of mast cells; magnification $=\times 100$. $\mathbf{d}$ Mast cells surrounding clusters of meningioma cells infiltrating the dura; magnification $=\times 400$. e One mast cell surrounded by meningioma cells; this mast cell does not appear to be degranulated. Bar $=15 \mu \mathrm{m}$ 

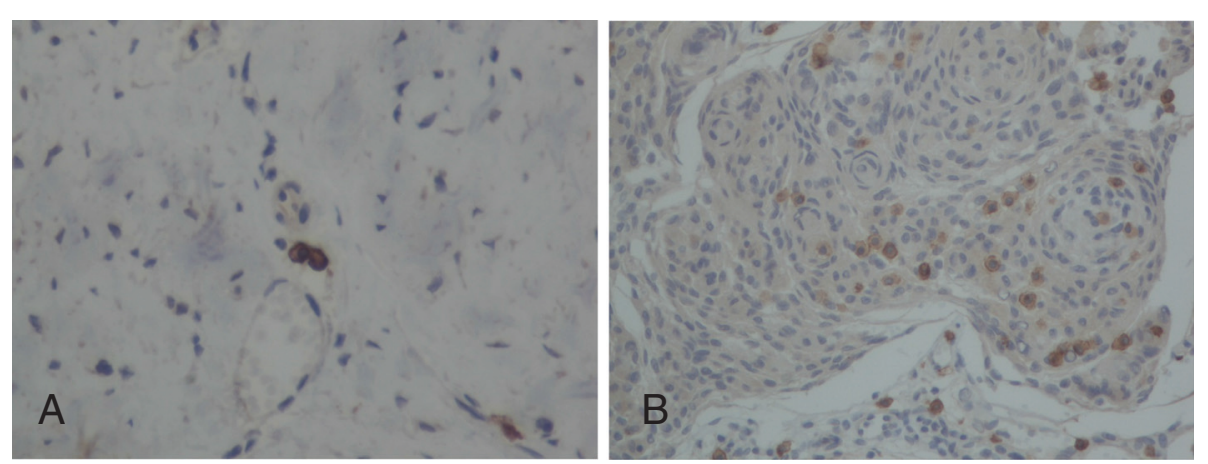

Fig. 2 Photomicrographs of tissue samples of dura infiltrated by meningioma of the meningothelial type grade I obtained from a brain lesion following a left-left frontotemporal craniectomy. Mast cells were stained immunohistochemically for the presence of CD117 (brown color). a Unaffected dura showing two mast cells. $\mathbf{b}$ Dura infiltrated by meningioma cells showing a number of mast cells (brown color). Magnification $=\times 200$

investigate the presence of occult meningiomas in such disorders.

\section{Treatment options}

Brain edema may be reduced with the use of glucocorticoids or anti-angiogenic therapy [77].

Cyclooxygenase (COX) inhibitors have also been considered for the treatment of brain edema [73, 90] especially because COX-2 expression has been reported in astrocyte and microglia in humans [91]. It is of interest that certain natural flavonoids, such as quercetin (3, 5, 7-3' 4'-pentahydroxyflavone), inhibit COX-2 and angiogenesis $[92,93]$, and its structural analog luteolin (5,7-3' 4' -tetrahydroxyflavone) inhibits COX-2 in glioblastoma cells [94]. Quercetin also has antiproliferative activity against human meningiomas [95] and gliomas [96, 97]. Luteolin has synergistic action with COX-2 inhibitors on inducing apoptosis of breast cancer cells [98].

Both quercetin [99] and luteolin inhibit MCs [99-101], especially MC-derived VEGF release. Luteolin also inhibits activation of auto-immune T cells $[102,103]$.

A methylated luteolin analog (6-methoxyluteolin) was shown to inhibit IgE-stimulated histamine release from human basophilic KU812F [104]. Moreover, we recently showed that tetramethoxyluteolin is a more potent inhibitor of human cultured MCs than luteolin [105].

Luteolin also inhibits activation and proliferation of microglia [106-109], which have been implicated in autism [110]. A luteolin/quercetin-containing formulation in olive fruit oil significantly improved attention and behavior in children with autism [111, 112]. It is interesting that oleocanthal present in olive oil was shown to have COX inhibitory activity [113].

Flavonoids are naturally occurring compounds found mostly in green plants, herbs, and seeds with potent antioxidant, anti-inflammatory, and anticancer properties
[114]. Recent reviews have discussed the use of flavonoids in neuropsychiatric $[115,116]$ and neurodegenerative $[117,118]$ diseases, especially luteolin in the prevention and/or treatment of brain fog [119].

\section{Conclusion}

There is growing evidence that the accumulation of MCs in meningiomas, mainly in perivascular areas, is associated with the presence of peritumoral edema, especially in high-grade tumors. Furthermore, meningeal MCs may contribute to edema and inflammation involved in headaches and possibly seizures. Finally, meningeal MCs may regulate permeability of the $\mathrm{BBB}$ and contribute to the pathogenesis of brain metastases, multiple sclerosis, and autism.

\section{Competing interest}

The authors declare that they have no competing interests.

\section{Authors' contributions}

SP carried out most of the literature search and wrote the original draft of the paper. TK carried out the immunohistochemical staining and produced the photomicrographs used. SP reviewed the literature and prepared the manuscript. KA provided information on the classification and reviewed the paper critically. TCT conceived the original concept, reviewed all the literature and the immunohistochemical findings, corrected earlier drafts of the manuscript, and prepared the final manuscript. All authors read and approved the final manuscript.

\section{Author details}

${ }^{1}$ Department of Neurosurgery, Kings College London, London, UK. 2Department of Pathology, AHEPA General Hospital, Thessaloniki, Greece. ${ }^{3}$ Molecular Immunopharmacology and Drug Discovery, Department of Integrative Physiology and Pathobiology, Tufts University School of Medicine, 136 Harrison Avenue, Suite J304, Boston, MA 02111, USA. ${ }^{4}$ Sackler School of Graduate Biomedical Sciences, Tufts University School of Medicine, Tufts Medical Center, Boston, MA, USA. ${ }^{5}$ Department of Internal Medicine, Tufts University School of Medicine, Tufts Medical Center, Boston, MA, USA. ${ }^{6}$ Department of Psychiatry, Tufts University School of Medicine, Tufts Medical Center, Boston, MA, USA. ${ }^{7}$ Department of Integrative Physiology and Pathobiology, Tufts University School of Medicine, 136 Harrison Avenue, Suite J304, Boston, MA 02111, USA. 
Received: 7 August 2015 Accepted: 1 September 2015 Published online: 17 September 2015

\section{References}

1. Rogers L, Barani I, Chamberlain M, Kaley TJ, McDermott M, Raizer J, et al. Meningiomas: knowledge base, treatment outcomes, and uncertainties. A RANO review. J Neurosurg. 2015;122:4-23.

2. Carroll RS, Zhang J, Black PM. Expression of estrogen receptors alpha and beta in human meningiomas. J Neurooncol. 1999;42:109-16.

3. Maxwell M, Galanopoulos T, Neville-Golden J, Antoniades HN. Expression of androgen and progesterone receptors in primary human meningiomas. J Neurosurg. 1993;78:456-62.

4. Probst-Cousin S, Villagran-Lillo R, Lahl R, Bergmann M, Schmid KW, Gullotta F. Secretory meningioma: clinical, histologic, and immunohistochemical findings in 31 cases. Cancer. 1997:79:2003-15.

5. Ostrom QT, Gittleman H, Farah P, Ondracek A, Chen Y, Wolinsky Y, et al. CBTRUS statistical report: primary brain and central nervous system tumors diagnosed in the United States in 2006-2010. Neuro Oncol. 2013:15 Suppl 2:ii1-56.

6. Madhusoodanan S, Patel S, Reinharth J, Hines A, Serper M. Meningioma and psychiatric symptoms: a case report and brief review. Ann Clin Psychiatry. 2015;27:126-33

7. Louis DN, Ohgaki H, Wiestler OD, Cavenee WK, Burger PC, Jouvet A, et al. The 2007 WHO classification of tumours of the central nervous system. Acta Neuropathol. 2007;114:97-109.

8. Mirimanoff RO, Dosoretz DE, Linggood RM, Ojemann RG, Martuza RL. Meningioma: analysis of recurrence and progression following neurosurgical resection. J Neurosurg. 1985;62:18-24.

9. Barbaro NM, Gutin PH, Wilson CB, Sheline GE, Boldrey EB, Wara WM. Radiation therapy in the treatment of partially resected meningiomas. Neurosurgery. 1987;20:525-8.

10. Smith SJ, Boddu S, Macarthur DC. Atypical meningiomas: WHO moved the goalposts? Br J Neurosurg. 2007;21:588-92.

11. Yang SY, Park CK, Park SH, Kim DG, Chung YS, Jung HW. Atypical and anaplastic meningiomas: prognostic implications of clinicopathological features. J Neurol Neurosurg Psychiatry. 2008;79:574-80.

12. Bret $P$, Gharbi $S$, Cohadon F, Remond J. Meningioma of the lateral ventricle. 3 recent cases. Neurochirurgie. 1989;35:5-12.

13. Ruttledge MH, Sarrazin J, Rangaratnam S, Phelan CM, Twist E, Merel P, et al. Evidence for the complete inactivation of the NF2 gene in the majority of sporadic meningiomas. Nat Genet. 1994;6:180-4.

14. Mawrin C, Perry A. Pathological classification and molecular genetics of meningiomas. J Neurooncol. 2010;99:379-91.

15. Phillips LE, Koepsell TD, van BG, Kukull WA, Gehrels JA, Longstreth Jr WT. History of head trauma and risk of intracranial meningioma: populationbased case-control study. Neurology. 2002;58:1849-52.

16. Preston-Martin S, Pogoda JM, Schlehofer B, Blettner M, Howe GR, Ryan P, et al. An international case-control study of adult glioma and meningioma: the role of head trauma. Int J Epidemiol. 1998;27:579-86.

17. Rossi ML, Cruz SF, Hughes JT, Esiri MM, Coakham HB. Immunocytochemical study of the cellular immune response in meningiomas. J Clin Pathol. 1988;41:314-9.

18. Bo L, Mork SJ, Nyland H. An immunohistochemical study of mononuclear cells in meningiomas. Neuropathol Appl Neurobiol. 1992;18:548-58.

19. Kepes JJ, Chen WY, Connors MH, Vogel FS. "Chordoid" meningeal tumors in young individuals with peritumoral lymphoplasmacellular infiltrates causing systemic manifestations of the Castleman syndrome. A report of seven cases. Cancer. 1988;62:391-406.

20. Rajaraman P, Brenner AV, Neta G, Pfeiffer R, Wang SS, Yeager M, et al. Risk of meningioma and common variation in genes related to innate immunity. Cancer Epidemiol Biomarkers Prev. 2010;19:1356-61.

21. Barnett GH, Chou SM, Bay JW. Posttraumatic intracranial meningioma: a case report and review of the literature. Neurosurgery. 1986;18:75-8.

22. Kunz T, Marklund N, Hillered L, Oliw EH. Cyclooxygenase-2, prostaglandin synthases, and prostaglandin $\mathrm{H} 2$ metabolism in traumatic brain injury in the rat. J Neurotrauma. 2002;19:1051-64.

23. Ragel BT, Jensen RL, Couldwell WT. Inflammatory response and meningioma tumorigenesis and the effect of cyclooxygenase-2 inhibitors. Neurosurg Focus. 2007;23:E7.
24. Reszec J, Hermanowicz A, Kochanowicz J, Turek G, Mariak Z, Chyczewski L. Mast cells evaluation in meningioma of various grades. Folia Histochem Cytobiol. 2012;50:542-6.

25. Lolova I, Ivanova A. A histochemical study of meningiomas. Acta Neuropathol. 1972;20:110-21.

26. Popovic EA, Lyons MK, Scheithauer BW, Marsh WR. Mast cell-rich convexity meningioma presenting as chronic subdural hematoma: case report and review of the literature. Surg Neurol. 1994;42:8-13.

27. Tascos NA, Parr J, Gonatas NK. Immunocytochemical study of the glial fibrillary acidic protein in human neoplasms of the central nervous system. Hum Pathol. 1982;13:454-8.

28. Christie KN, Stoward PJ. Endogenous peroxidase in mast cells localized with a semipermeable membrane technique. Histochem J. 1978;10:425-33.

29. Reszec J, Hermanowicz A, Rutkowski R, Bernaczyk P, Mariak Z, Chyczewski L. Evaluation of mast cells and hypoxia inducible factor-1 expression in meningiomas of various grades in correlation with peritumoral brain edema. J Neurooncol. 2013;115:119-25.

30. Jabini R, Moradi A, Afsharnezhad S, Ayatollahi H, Behravan J, Raziee HR, et al. Pathodiagnostic parameters and evaluation of O(6)- methyl guanine methyl transferase gene promoter methylation in meningiomas. Gene. 2014:538:348-53.

31. Gilfillan AM, Austin SJ, Metcalfe DD. Mast cell biology: introduction and overview. Adv Exp Med Biol. 2011;716:2-12.

32. Ribatti $D$, Crivellato E. Mast cells, angiogenesis, and tumour growth. Biochim Biophys Acta. 1822;2012:2-8.

33. Theoharides TC, Conti P. Mast cells: the JEKYLL and HYDE of tumor growth. Trends Immunol. 2004;25:235-41.

34. Theoharides TC, Valent P, Akin C. Mast cells, mastocytosis and related diseases. New Engl J Med. 2015. in press

35. Theoharides TC, Stewart JM, Panagiotidou S. Mast Cells, Brain Inflammation and Autism. Eur J Pharmacol. 2015. in press

36. Dimitriadou V, Rouleau A, Trung Tuong MD, Newlands GJF, Miller HRP, Luffau $G$, et al. Functional relationships between sensory nerve fibers and mast cells of dura mater in normal and inflammatory conditions. Neuroscience. 1997;77:829-39.

37. Silver R, Curley JP. Mast cells on the mind: new insights and opportunities. Trends Neurosci. 2013.

38. Theoharides TC, Angelidou A, Alysandratos KD, Zhang B, Asadi S, Francis $K$, et al. Mast cell activation and autism. Biochim Biophys Acta. 1822;2012:34-41.

39. Theoharides TC. Mast cells: the immune gate to the brain. Life Sci. 1990:46:607-17.

40. Theoharides TC, Konstantinidou A. Corticotropin-releasing hormone and the blood-brain-barrier. Front Biosci. 2007;12:1615-28.

41. Esposito P, Chandler N, Kandere-Grzybowska K, Basu S, Jacobson S, Connolly $\mathrm{R}$, et al. Corticotropin-releasing hormone $(\mathrm{CRH})$ and brain mast cells regulate blood-brain-barrier permeability induced by acute stress. J Pharmacol Exp Ther. 2002;303:1061-6.

42. Theoharides TC, Kalogeromitros D. The critical role of mast cell in allergy and inflammation. Ann NY Acad Sci. 2006;1088:78-99.

43. Ribatti D. The crucial role of mast cells in blood-brain barrier alterations. Exp Cell Res. 2015

44. Nelissen S, Lemmens E, Geurts N, Kramer P, Maurer M, Hendriks J, et al. The role of mast cells in neuroinflammation. Acta Neuropathol. 2013;125:637-50.

45. Skaper SD, Facci L, Giusti P. Mast cells, glia and neuroinflammation: partners in crime? Immunology. 2014;141:314-27.

46. Theoharides TC, Zhang B. Neuro-Inflammation, blood-brain barrier, seizures and autism. J Neuroinflammation. 2011:8:168.

47. Skaper SD, Facci L, Giusti P. Mast cells, glia and neuroinflammation: partners in crime? Immunology. 2014;141:314-27.

48. Theoharides TC, Donelan J, Kandere-Grzybowska K, Konstantinidou A. The role of mast cells in migraine pathophysiology. Brain Res Rev. 2005;49:65-76.

49. Theoharides TC, Asadi S, Patel A. Focal brain inflammation and autism J Neuroinflammation. 2013;10:46.

50. Vasiadi M, Newman J, Theoharides TC. Isoflavones inhibit poly(l:C)-induced serum, brain, and skin inflammatory mediators - relevance to chronic fatigue syndrome. J Neuroinflammation. 2014;11:168.

51. Hoogland IC, Houbolt C, van Westerloo DJ, van Gool WA, van de BD. Systemic inflammation and microglial activation: systematic review of animal experiments. J Neuroinflammation. 2015;12:114. 
52. Ribatti D. Mast cells as therapeutic target in cancer. Eur J Pharmacol. 2015

53. Polajeva J, Sjosten AM, Lager N, Kastemar M, Waern I, Alafuzoff I, et al. Mast cell accumulation in glioblastoma with a potential role for stem cell factor and chemokine CXCL12. PLoS ONE. 2011;6:e25222

54. Polajeva J, Bergstrom T, Edqvist PH, Lundequist A, Sjosten A, Nilsson G, et al. Glioma-derived macrophage migration inhibitory factor (MIF) promotes mast cell recruitment in a STAT5-dependent manner. Mol Oncol. 2014;8:50-8.

55. Kumar P, Kumar S, Marsden HB, Lynch PG, Earnshaw E. Weibel-Palade bodies in endothelial cells as a marker for angiogenesis in brain tumors. Cancer Res. 1980;40:2010-9.

56. Tachibana O, Yamashima T, Yamashita J. Immunohistochemical study of erythropoietin in cerebellar hemangioblastomas associated with secondary polycythemia. Neurosurgery. 1991;28:24-6.

57. Theoharides TC, Rozniecki JJ, Sahagian G, Kempuraj D, Kalogeromitros D, Conti P. Impact of stress and mast cells on brain metastases. J Neuroimmunol. 2008:205:1-7.

58. Esposito P, Jacobson S, Connolly R, Gheorghe D, Theoharides TC. Non-invasive assessment of blood-brain barrier (BBB) permeability using a gamma camera to detect ${ }^{99}$ Technetium-gluceptate extravasation in rat brain. Brain Res Protocols. 2001;8:143-9.

59. Rozniecki JJ, Sahagian GG, Kempuraj D, Tao K, Jocobson S, Zhang B, et al. Brain metastases of mouse mammary adenocarcinoma is increased by acute stress. Brain Res. 2010;1366:204-10.

60. Sayegh ET, Henderson GA, Burch EA, Reis GF, Cha S, Oh T, et al. Intrameningioma metastasis of breast carcinoma. Rare Tumors. 2014;6:5313.

61. Okada E, Nakamura M, Koshida Y, Mukai K, Toyama Y, Matsumoto M. Breast carcinoma metastasis to meningioma in the thoracic spine: a case report and review of the literature. J Spinal Cord Med. 2015:38:231-5.

62. Milano MT, Grossman CE. Meningioma in breast cancer patients: population-based analysis of clinicopathologic characteristics. Am J Clin Oncol. 2014

63. Theoharides TC. Mast cells and pancreatic cancer. N Engl J Med. 2008;358:1860-1.

64. Jensen RL. Brain tumor hypoxia: tumorigenesis, angiogenesis, imaging, pseudoprogression, and as a therapeutic target. J Neurooncol. 2009:92:317-35.

65. Kazner E, Lanksch W, Steinhoff H, Wilske J. Computerized axial tomography of the skull - diagnostic possibilities and clinical results (author's transl). Fortschr Neurol Psychiatr Grenzgeb. 1975;43:487-574.

66. Tirakotai W, Mennel HD, Celik I, Hellwig D, Bertalanffy H, Riegel T. Secretory meningioma: immunohistochemical findings and evaluation of mast cell infiltration. Neurosurg Rev. 2006;29:41-8.

67. Epari S, Sharma MC, Sarkar C, Garg A, Gupta A, Mehta VS. Chordoid meningioma, an uncommon variant of meningioma: a clinicopathologic study of 12 cases. J Neurooncol. 2006;78:263-9.

68. Tena-Suck ML, Collado-Ortiz MA, Salinas-Lara C, Garcia-Lopez R, Gelista N, Rembao-Bojorquez D. Chordoid meningioma: a report of ten cases. J Neurooncol. 2010;99:41-8.

69. Schober R, Himuro $H$, Wechsler W. Cystic changes and vascular permeability in meningiomas. Clin Neuropathol. 1988;7:16-21.

70. Karamitopoulou E, Shoni M, Theoharides TC. Increased number of non-degranulated mast cells in pancreatic ductal adenocarcinoma but not in acute pancreatitis. Int J Immunopathol Pharmacol. 2014;27:213-20.

71. Abe T, Black PM, Ojemann RG, Hedley-White ET. Cerebral edema in intracranial meningiomas: evidence for local and diffuse patterns and factors associated with its occurrence. Surg Neurol. 1994;42:471-5.

72. Buhl $\mathrm{R}$, Hugo HH, Mehdorn HM. Brain oedema in secretory meningiomas. J Clin Neurosci. 2001;8 Suppl 1:19-21.

73. Wick W, Kuker W. Brain edema in neurooncology: radiological assessment and management. Onkologie. 2004;27:261-6.

74. Nakano T, Asano K, Miura H, Itoh S, Suzuki S. Meningiomas with brain edema: radiological characteristics on MRI and review of the literature. Clin Imaging. 2002;26:243-9.

75. Machein MR, Plate KH. VEGF in brain tumors. J Neurooncol. 2000;50:109-20.

76. Nassehi D. Intracranial meningiomas, the VEGF-A pathway, and peritumoral brain oedema. Dan Med J. 2013;60:B4626.

77. Hou J, Kshettry VR, Selman WR, Bambakidis NC. Peritumoral brain edema in intracranial meningiomas: the emergence of vascular endothelial growth factor-directed therapy. Neurosurg Focus. 2013;35:E2.
78. Cao J, Papadopoulou N, Kempuraj D, Boucher WS, Sugimoto K, Cetrulo CL, et al. Human mast cells express corticotropin-releasing hormone (CRH) receptors and $\mathrm{CRH}$ leads to selective secretion of vascular endothelial growth factor. J Immunol. 2005;174:7665-75.

79. Kempuraj D, Papadopoulou NG, Lytinas M, Huang M, Kandere-Grzybowska K, Madhappan B, et al. Corticotropin-releasing hormone and its structurally related urocortin are synthesized and secreted by human mast cells. Endocrinology. 2004;145:43-8.

80. Shahani S, Nudelman RJ, Nalini R, Kim HS, Samson SL. Ectopic corticotropin-releasing hormone $(\mathrm{CRH})$ syndrome from metastatic small cell carcinoma: a case report and review of the literature. Diagn Pathol. 2010;5:56.

81. Feoktistov A, Diamond M. Diagnosing and understanding adult headache. Otolaryngol Clin North Am. 2014;47:175-85.

82. Smith RM, Robertson CE, Garza I. Orthostatic headache from supratentorial meningioma. Cephalalgia. 2015

83. Heron A, Dubayle D. A focus on mast cells and pain. J Neuroimmunol. 2013;264:1-7.

84. Hancock BW, Dandona P, Cumberland DC, Jarratt JA. Systemic mastocytosis-central nervous system features and lymphographic demonstration of lymph node involvement. Postgrad Med J. 1976:52:659-62.

85. Ransohoff RM. Immunology: barrier to electrical storms. Nature. 2009;457:155-6.

86. Pehlivanidis C, Fotoulaki M, Boucher W, Kempuraj D, Pang X, Konstantinidou $A$, et al. Acute stress-induced seizures and loss of consciousness in a ten-year-old boy with cutaneous mastocytosis. J Clin Psychopharmacol. 2002;22:221-4

87. Karagkouni A, Alevizos M, Theoharides TC. Effect of stress on brain inflammation and multiple sclerosis. Autoimmun Rev. 2013;12:947-53.

88. Bradstreet JJ, Pacini S, Ruggiero M. A new methodology of viewing extra-axial fluid and cortical abnormalities in children with autism via transcranial ultrasonography. Front Hum Neurosci. 2014;7:934.

89. Theoharides TC, Stewart JM, Hatziagelaki E, Kolaitis G. Brain "fog," inflammation and obesity: key aspects of 2 neuropsychiatric disorders improved by luteolin. Front. Neurosci. 2015. in press

90. Roth P, Regli L, Tonder M, Weller M. Tumor-associated edema in brain cancer patients: pathogenesis and management. Expert Rev Anticancer Ther. 2013;13:1319-25.

91. Temel SG, Kahveci Z. Cyclooxygenase-2 expression in astrocytes and microglia in human oligodendroglioma and astrocytoma. J Mol Histol. 2009:40:369-77.

92. Xiao X, Shi D, Liu L, Wang J, Xie X, Kang T, et al. Quercetin suppresses cyclooxygenase-2 expression and angiogenesis through inactivation of P300 signaling. PLoS ONE. 2011;6:e22934.

93. de Pascual-Teresa S, Johnston KL, DuPont MS, O'Leary KA, Needs PW, Morgan LM, et al. Quercetin metabolites downregulate cyclooxygenase-2 transcription in human lymphocytes ex vivo but not in vivo. J Nutr. 2004;134:552-7.

94. Lamy S, Moldovan PL, Ben SA, Annabi B. Biphasic effects of luteolin on interleukin-1 beta-induced cyclooxygenase-2 expression in glioblastoma cells. Biochim Biophys Acta. 1853;2015:126-35.

95. Piantelli M, Rinelli A, Macri E, Maggiano N, Larocca LM, Scerrati M, et al. Type II estrogen binding sites and antiproliferative activity of quercetin in human meningiomas. Cancer. 1993;71:193-8.

96. Park MH, Min dS. Quercetin-induced downregulation of phospholipase D1 inhibits proliferation and invasion in U87 glioma cells. Biochem Biophys Res Commun. 2011:412:710-5.

97. Braganhol E, Zamin LL, Canedo AD, Horn F, Tamajusuku AS, Wink MR, et al. Antiproliferative effect of quercetin in the human U138MG glioma cell line. Anticancer Drugs. 2006;17:663-71.

98. Jeon YW, Suh YJ. Synergistic apoptotic effect of celecoxib and luteolin on breast cancer cells. Oncol Rep. 2013;29:819-25.

99. Kempuraj D, Madhappan B, Christodoulou S, Boucher W, Cao J, Papadopoulou N, et al. Flavonols inhibit proinflammatory mediator release intracellular calcium ion levels and protein kinase C theta phosphorylation in human mast cells. Br J Pharmacol. 2005;145:934-44.

100. Kimata M, Shichijo M, Miura T, Serizawa I, Inagaki N, Nagai H. Effects of luteolin, quercetin and baicalein on immunoglobulin E-mediated mediator release from human cultured mast cells. Clin Exp Allergy. 2000;30:501-8. 
101. Asadi S, Zhang B, Weng Z, Angelidou A, Kempuraj D, Alysandratos KD, et al. Luteolin and thiosalicylate inhibit $\mathrm{HgCl}(2)$ and thimerosal-induced VEGF release from human mast cells. Int J Immunopathol Pharmacol. 2010;23:1015-20.

102. Kempuraj D, Tagen M, lliopoulou BP, Clemons A, Vasiadi M, Boucher W, et al. Luteolin inhibits myelin basic protein-induced human mast cell activation and mast cell dependent stimulation of Jurkat $\mathrm{T}$ cells. $\mathrm{Br}$ J Pharmacol. 2008;155:1076-84.

103. Verbeek R, Plomp AC, van Tol EA, van Noort JM. The flavones luteolin and apigenin inhibit in vitro antigen-specific proliferation and interferon-gamma production by murine and human autoimmune T cells. Biochem Pharmacol. 2004;68:621-9.

104. Shim SY, Park JR, Byun DS. 6-Methoxyluteolin from Chrysanthemum zawadskii var. latilobum suppresses histamine release and calcium influx via down-regulation of FcepsilonRI alpha chain expression. J Microbiol Biotechnol. 2012;22:622-7.

105. Weng Z, Patel A, Panagiotidou S, Theoharidess TC. The novel flavone tetramethoxyluteolin is a potent inhibitor of human mast cells. J Allergy Clin Immunol. 2014;14:1044-52.

106. Jang S, Kelley KW, Johnson RW. Luteolin reduces IL-6 production in microglia by inhibiting JNK phosphorylation and activation of AP-1. Proc Natl Acad Sci U S A. 2008;105:7534-9.

107. Dirscherl K, Karlstetter M, Ebert S, Kraus D, Hlawatsch J, Walczak Y, et al. Luteolin triggers global changes in the microglial transcriptome leading to a unique anti-inflammatory and neuroprotective phenotype. J Neuroinflammation. 2010;7:3.

108. Chen HQ, Jin ZY, Wang XJ, Xu XM, Deng L, Zhao JW. Luteolin protects dopaminergic neurons from inflammation-induced injury through inhibition of microglial activation. Neurosci Lett. 2008;448:175-9.

109. Kao TK, Ou YC, Lin SY, Pan HC, Song PJ, Raung SL, et al. Luteolin inhibits cytokine expression in endotoxin/cytokine-stimulated microglia. J Nutr Biochem. 2011;22:612-24

110. Gupta S, Ellis SE, Ashar FN, Moes A, Bader JS, Zhan J, et al. Transcriptome analysis reveals dysregulation of innate immune response genes and neuronal activity-dependent genes in autism. Nat Commun. 2014:5:5748

111. Theoharides TC, Asadi S, Panagiotidou S. A case series of a luteolin formulation (NeuroProtek(R)) in children with autism spectrum disorders. Int J Immunopathol Pharmacol. 2012;25:317-23.

112. Taliou A, Zintzaras E, Lykouras L, Francis K. An open-label pilot study of a formulation containing the anti-inflammatory flavonoid luteolin and its effects on behavior in children with autism spectrum disorders. Clin Ther. 2013;35:592-602

113. Beauchamp GK, Keast RS, Morel D, Lin J, Pika J, Han Q, et al. Phytochemistry: ibuprofen-like activity in extra-virgin olive oil. Nature. 2005;437:45-6.

114. Middleton EJ, Kandaswami C, Theoharides TC. The effects of plant flavonoids on mammalian cells: implications for inflammation, heart disease and cancer. Pharmacol Rev. 2000;52:673-751.

115. Jager AK, Saaby L. Flavonoids and the CNS. Molecules. 2011:16:1471-85.

116. Grosso C, Valentao P, Ferreres F, Andrade PB. The use of flavonoids in central nervous system disorders. Curr Med Chem. 2013;20:4697-719.

117. Solanki I, Parihar P, Mansuri ML, Parihar MS. Flavonoid-based therapies in the early management of neurodegenerative diseases. Adv Nutr. 2015;6:64-72.

118. Jones QR, Warford J, Rupasinghe HP, Robertson GS. Target-based selection of flavonoids for neurodegenerative disorders. Trends Pharmacol Sci. 2012;33:602-10.

119. Theoharides TC, Stewart JM, Hatziagelaki E, Kolaitis G. Brain "fog", inflammation and obesity: key aspects of neuropsychiatric disorders improved by luteolin. Front Neurosci. 2015;9:225.

\section{Submit your next manuscript to BioMed Central and take full advantage of:}

- Convenient online submission

- Thorough peer review

- No space constraints or color figure charges

- Immediate publication on acceptance

- Inclusion in PubMed, CAS, Scopus and Google Scholar

- Research which is freely available for redistribution 